\title{
Prioritize Agri-Environmental Measures of Water-Related Ecosystem Services: The Case of Mashhad
}

\author{
A. Firoozzare ${ }^{1}$, M. Ghorbani ${ }^{1}$, A. R. Karbasi ${ }^{1}$, N. Shahnoushi ${ }^{1} \&$ K. Davari ${ }^{2}$ \\ ${ }^{1}$ Department of Agricultural Economics, Faculty of Agriculture, Ferdowsi University of Mashhad, Iran \\ ${ }^{2}$ Department of Water Science and Engineering, Faculty of Agriculture, Ferdowsi University of Mashhad, Iran \\ Correspondence: M. Ghorbani, Department of Agricultural Economics, Faculty of Agriculture, Ferdowsi \\ University of Mashhad, Azadi Square, Mashhad, Razavi Khorasan Province, Iran. Tel: 98-51-3880-5785. E-mail: \\ ghorbani@um.ac.ir
}

Received: January 6, 2018

Accepted: January 30, 2018 Online Published: July 29, 2018

doi:10.5539/jsd.v11n4p240

URL: https://doi.org/10.5539/jsd.v11n4p240

\begin{abstract}
Current structure of agricultural input consumption eventually influences bases of natural environment and ecosystem services (especially water related) from which human communities benefit. This research aims at assisting decision making and prioritizing ecosystem services and their improvement measures according to interconnection of different ecosystem services and agri-environmental schemes of improving these services with help of fuzzy analytic network process (FANP) in Mashhad plain. Results show that among water-related ecosystem services, water quality and having healthy products, are first priorities. Providing needed water for agriculture section stands in the second rank with minor difference. Third and fourth places go to soil conservation and biodiversity relatively and agricultural tourism which is categorized under cultural services is placed in the last place. Also, based on this study results, among the seven agri-environmental water-related ecosystem services improvement, integrated pest management (IPM) ranks first. The second and third priorities belong to proposed crop pattern and conservative tillage implementation.
\end{abstract}

Keywords: agriculture, ecosystem, fuzzy set theory, Chang's extended analysis

\section{Introduction}

The rapid population growth has brought up severe food need and therefore have a most important influence on agricultural production, resulting in transformations in agricultural systems in order to answer the demands of growing markets (Rigg, 1998; Robinson \& Carson, 2015; Theobald, 2001; Zasada, 2011; Song et al., 2017). These changes have main pressures on agro-ecological systems, often changing the ecosystem services they prepare. These services can be affected by transforms in agricultural production (Song et al., 2017). Agricultural influences usually roots in inappropriate treatment of agricultural producers who use chemical fertilizers, poisons and other agricultural inputs inappropriately that causes destruction of ecological environment. The unprecedented increase in agricultural products during the last 60 years as a result of agricultural policies and advanced equipments, has brought up a considerable cost to natural environment and biodiversity of agricultural lands (Javadzadeh, 2014). In addition, due to the fact that Iranian agricultural structure is basically short-scale and familial, farmers are not usually familiar with dangers of inappropriate use of chemical fertilizers and poisons. On the other hand, avoiding chemical fertilizers and poisons reduces the amount of products. In Iran, a cycle of different challenges like increasing of population in the last 30 years and reduction of arable lands, increasing ecological pressure in agricultural lands, misuse and destruction of water resources, not being cost effective and lack of efficiency in main inputs (land and water) have led to the highly unstable economic sector over the time (Darvishi, 1993). Also, based on a number of investigations it is said that chemical fertilizers and poisons of agricultural sector are considered as one of the contamination sources of Mashhad aquifer (northeast of Iran) (Monitoring network, 2012). According to Einollahi (2013) trend of using chemical ferilizers in agricultural sector of Iran is duplicated during last 10 years and its current annual usage is about 5.4 million tones.

Unless the current structure of agricultural input consumption is revised in a short time, producing agricultural products will eventually influence bases of natural environment and ecosystem services (especially water related) from which human communities benefit. Ecosystem services are those which are directly or indirectly provided by ecosystem and include products (clean water, fuel and healthy food), natural process adjustment (climate, flood, 
erosion) and non product benefits (recreational and aesthetic pleasure) and support services. The definition of ecosystem is the main part of the environmental framework in any policy (Haines-Young et al, 2012; Hughes and Brooks, 2009; Scottish Government, 2011; UKNEA, 2011).

The concept of ecosystem services was introduced in 1981 as a combined proposal of economists and ecologists (Ehrlich \& Ehrlich, 1981). Ecosystem services are defined as the benefits that people obtain from ecosystems (MEA, 2005), and the direct and indirect contributions of ecosystems to human well-being (TEEB, 2010). The concept of ecosystem services is relevant for connecting people to nature. It makes visible the key role of ecosystem functioning and biodiversity to support multiple benefits to humans. Understanding the linkages between the natural and socio-economic systems can lead to improved and more sustainable management of ecosystems (Grizzetti et al., 2016; Guerry et al., 2015). There is a growing appreciation of the important role that ecosystems play in providing goods and services that contribute to human welfare, and recognition of the impact of human actions on ecosystems (Ojea et al. 2012). The Millennium Ecosystem Assessment has shown that one of these ecosystems is water-related ecosystem (MEA, 2005).

Being one of the most important natural resources, water has been directly threatened by human activities (Vörösmarty, et al., 2010). It is considered a main element in sustainable development. Water is important in three aspects; first, it is a final product. Secondly, it is considered an input in economic activities and lastly, it is a vital medium in environmental functions. On the other hand, several challenges rooted in water threaten human beings such as floods and drought. Reaching sustainable development without trying for development in water is barely possible, if not impossible.

According to MEA (2005), water-related ecosystem services (WES) associated to balance and flood control, water rules and systems, soil erosion control and water purification are considered regulating services, habitat function is considered a supporting service and water dispersion is considered a provisioning service (Lele, 2009). In other words, in MEA, water is considered a provisioning service because it is associated with domestic use, irrigation in agriculture, producing electricity and in transportation. However, water and its hydrological cycle support aquatic ecosystems such as rivers, lakes and etc, these ecosystems provide regulating, cultural and supporting services which are directly or indirectly effective on human beings well-fare in forms of free recreational services, tourism, existential values and preservation of water quality and etc. table 1 summarizes water-related ecosystem services and its hydrological cycle.

Table 1. Water-related ecosystem services and its hydrological cycle

\begin{tabular}{|c|c|c|}
\hline Provisioning services & Regulating services & Cultural services \\
\hline $\begin{array}{l}\text { - Water, (quality and quantity) for } \\
\text { consumption (drinking, } \\
\text { domestic, agriculture) } \\
\text { - Water for non-consumption } \\
\text { (producing electricity, } \\
\text { transportation) } \\
\text { Water organisms for food and } \\
\text { drugs }\end{array}$ & $\begin{array}{l}\text { Preserving water } \\
\text { quality (natural } \\
\text { purification) } \\
\text { flood control, erosion } \\
\text { control using the } \\
\text { interaction of water } \\
\text { and land }\end{array}$ & $\begin{array}{ll}\text { - } & \text { Recreation (kayaks, } \\
\text { fishing, ...) as sport } \\
\text { - } & \text { Tourism (river tour) } \\
\text { - } & \text { Existential values } \\
\text { (personal and innate } \\
\text { satisfaction of rivers' free } \\
\text { flow) }\end{array}$ \\
\hline
\end{tabular}

\section{Supporting services}

- Place in food chain (Preserving fertile plain) and primary production

- Reversible ecosystem and relation between hunters and preys

Source: Ecosystems and Human Well-Being: Policy Responses (Chopra et al., 2005)

In order to preserve this ecosystem and its related services, natural balance of environment becomes the focus of scientific and functional circles and a wide range of environmental policies and schemes based on standards and environmental rules, tax, payment and salable permits were enacted to overcome the public market failure and external influence of agricultural section. Researches show that there is no single tool to preserve environment completely and for such end, it is needed for political groups and communities to blend these tools. But in the mid 80 s, after recognizing the agriculture related damages to the ecosystem and related services and proper management of agriculture and ecosystems relations, agri-environmental schemes were introduced. These are the 
most effective tools for development of agriculture and environmental relations (OECD, 2003). Reducing environmental risks, preserving beauty and biodiversity of fields, development of system, increasing chances of recreation for countryside and guarding the historical elements are some of the goals of agri-environmental schemes (AES).

The main goal of AES is to support environmentally beneficial measures including sustainable agriculture and preserving existing low intensity system. Although in different countries, different priorities exist (European Commission, 1997).

In Iran and specially in Mashhad plain, based on authentic documents and regulations as well as water-related ecosystems studies, we can say that in most documents, development of water and soil consumption pattern, dedicating water to more economically valuable products, not exceeding the basin's capacity, balance and improvement of aquifers, attention to and enhancing water quality parameters and requiring people to follow national standards of qualitative preservation of water resource for waste water, participation of all relevant organizations as well as augmenting the role of public and stakeholders and local organizations as well as extensive research and investment by justifying the intrinsic value of water resources, government support and budget dedication is required. Furthermore, it has to be taken into account that one should avoid top down policies in opposition to caring for stakeholders in decision making of this area (The general policies of the I.R. Iran, 2003; Islamic Parliament of I.R. Iran, 2011; The Council of Ministers of I.R. Iran, 2003; The Council of Ministers of I.R. Iran, 2005; The Council of Ministers of I.R. Iran, 2008; Ministry of Power of I.R. Iran, 2009; Davari et al., 2015).

Considering these and due to the fact that it is necessary that all proposed programs are in line with authentic documents and regulations and also multiplicity of proposed strategies in relevant documents. It seems that with specific goals and multiple techniques, priorities of agri-environmental measures in each of these areas will greatly help us in achieving our goals and guiding the authorities of this area to use guided policies and smart and balanced allocation of budgets.

For this end, the current research aims at assisting decision making and prioritizing ecosystem services and their improvement measures according to interconnection of different ecosystem services and agri-environmental measures of improving these services with help of fuzzy analytic network process based on the view point of experts and beneficiaries in Mashhad plain (Iran).

\section{Materials and Methods}

\subsection{Study Area}

Mashhad plain which is among the most important plains of Khorasan-e-Razavi province in northeast of Iran, is bound to Neyshabour and Yengije on the west, Kalat and quchan plains on the north, Fariman and Kalat plains on the east and Fariman, Sangbast and Neyshabour on the south and its general underground water flow direction is from north west to south east.

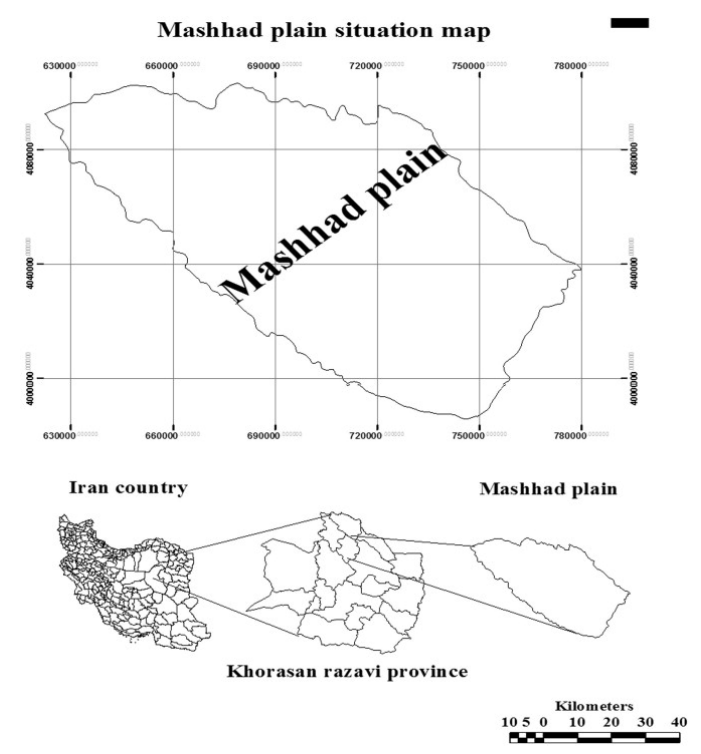

Map 1. situation of Mashhad plain in Khorasan-e-Razavi province 
In general, we can divide Mashhad water supplies into four groups: underground water resources, regulated surface water (runoff) resources, irregulated surface water resources and re use of waste water (Shahnoushi, 2014).

a) Underground water resources- due to excessive use of underground water resources such as Mashhad Chenaran aquifer and reduction of underground renewable resources caused by lack of precipitations, a continuous lowering in Water level of Mashhad aquifer has occurred and it is facing a shortage of about 88 million cubic meters, therefore, this plain was listed under prohibited plain and utilization and allocation of that should follow the rules of prohibited plains and be in accordance with fair water distribution law. According to provided statistics in year 2014, there are 6716 wells, 1085 aqueducts and 656 springs in this plain that are a total of 1071 million cubic meters of water depletion.

b) Regulated surface water resources- Toroq, Kardeh, Dolatabad, Esjil and Chalidareh dams are located in Mashhad-Chenaran plain whose capacities reach 64.8 million cubic meters on a normal scale, needless to say that due to the climate of Iran and Khorasan Razavi province, the stored volume is usually less than the normal and about one third of normal amount. stored water behind Toroq and Kardeh dams is used for drinking and that of Dolatabad and Chalidareh dams for agriculture and watering gardens. With regard to the implementation and operation of Dusti dam in Mashhad with a capacity of 150 million cubic meters per year, almost 410 million meters is transferred to Mashhad - Chenaran plain, mostly for rural and urban drinking purposes and a little to services and industry.

c) Irregulated surface water resources- permanent rivers are another resource for water supply, but they don't exist in mashhad- chenaran plain and are merely responsible for housing seasonal floods which are in times used for agriculture, growing freshwater fish and supply of tank water. These rivers are normally located in high areas of the plain and are dry during hot times of the year. According to available statistics, the resulted runoff water from precipitations supplies about 281 million cubic meters of irregulated water (Shahnoushi, 2014).

d) Re-use of waste water - a growing need for water and lack of available water resources make waste water more valuable. At the moment, the output of Mashhad refineries is about 45 million cubic meters which is utilized in several ways depending on type and treatment method.

The hydrograph of Mashhad plain shows a sharp drop (23 meters drop in 29 years) in aquifers and it is predicted that in near future (10 to 50 years), it will face a critical and irrecoverable problem in supplying drinking water and water for industrial and agricultural uses (Shahnoushi, 2014).

According to statistics provided by comprehensive system of agricultural beneficiaries of Jahad-e-Keshavarzi office in Mashhad (2016), 8800 agricultural beneficiaries in cultivation subsection in Tabadkan, Darzab, Sarjam, Toos, Kardeh, Kenevist, Miami and Mian-Velayat Rural district are active. It is to be mentioned that according to the administrative division map of Iran in 2015, these 8 Rural district include 328 villages.

\subsection{Method}

In the hierarchical analysis process proposed by Saati (1994), selecting ecosystem services and agri-environmental measures for improvement of these services are categorized hierarchically. Therefore, different elements of AHP being goal, criteria and measure are related in a top-down process. AHP model is based on a logical assumption that decision making can be classified in a top-down linear hierarchy. Upper nodes in this hierarchy are not dependant on lower nodes and neither are the components of each node. This one-sided network cannot account for all interactions and complex feedback available in a system. To avoid this limitation, current problem is designed by analytic network process (ANP) proposed by Saati in 1996. It's a generalized version of AHP with goals, criteria and measures as clusters within which all interactions between clusters and components are reviewed. Since ANP was proposed by Saaty, it has been widely used for dealing with dependence and feedback decision-making problem. The method finds essential application in various decision-making processes by academics and practitioners (Chang et al. 2015). In recent years, analytic network process has been used in solving many complicated decision-making problems because it is a comprehensive multi-purpose decision making method. There are many studies and applications on ANP. Najafinasab et al. (2015) have applied analytical network process (ANP) method with fuzzy logic to select criteria and outline the importance of integrating sea and land criteria in the context of land-use planning in coastal areas of Iran. Shafiee (2015) in order to select the best strategy of mitigating the risks associated with offshore wind farms based on four comparison criteria: safety, added value, cost and feasibility has used fuzzy ANP method. Chang et al. (2015) adopted the fuzzy analytic network process method to evaluate the risk level for both intra-organizational cultures and for different industries in implementing an enterprise resource planning system. In addition, Kumar and Maiti (2012) in order to model risk based maintenance policy for an industrial unit has employed fuzzy analytic network process 
and Atmaca and Basar (2012) attempts to determine the suitability of existing power plants in Turkey and the plants that are being considered for establishment in the near future by applying analytical network process.

This study aims to apply fuzzy analytic network process technique in order to discover the water-related ecosystem services' priorities in Mashhad agriculture. Decision making in this area has to be made on the basis of influence of these measures have on different ecosystem services.

As we had before, ANP is a dependency and feedback based process which uses a network structure to analyze decision making problems. The value of approximate importance of a decision is presented on a 1-9 scale. Four steps of this method are:

1) Decision problem understanding- Assume that one measure is to be selected from a bunch of potential measures; here the decision problem is choosing a measure with the highest score.

2) Making sure that decision problem can be solved with ANP method- Analytic network process is suitable for network structured problems, those having a simple hierarchical structure can be resolved with AHP.

3) Decomposing the unstructured problem into several manageable and measurable units- On top, there is the decision problem and down below is usually the scenario or measure.

4) Assigning the person responsible for decision making- A small group of experts or managers is usually enough for presenting useful data.

In addition, instead of crisp values, fuzzy sets were used as decision variables. Using fuzzy sets theory allows incomplete and immeasurable data to enter the decision making design. Also, presenting information in the form of intervals makes it easier to express in the form of single numeric values for decision makers. As a result, pair-wise comparisons for each measure were changed to fuzzy intervals in order to consider inherent uncertainties in the decisions.

Due to the fact that ANP is only applicable in crisp values, Chang's extended analysis for fuzzy pair-wise comparison matrix has been used to obtain crisp priority weights. Then, in order to achieve limiting matrix, first these weights were normalized and then were raised to higher powers. This limiting matrix has equal columns which are the last priority of ANP model elements. Details of the methodology are presented in the following section.

\subsection{Development of the Network Model for Ecosystem Services Improvement}

According to the Millennium Ecosystem Assessment (MEA), ecosystem services may be divided into provisioning services, regulating services, and cultural services, all of which have direct effects on human well-being, together with the supporting services that are necessary to maintain the services within these three overall categories (MEA, 2005; Yang et al., 2015). In this study, water-related agri-environmental measures (which are recognized and considered by MEA, 2005; Chopra et al., 2005; Lele, 2009; Ran et al. 2013) are prioritized according to each mentioned groups of ecosystem services' criteria and their feedback, interconnections and corrective agri-environmental measures with each other.

Therefore, analytic network process model which is used in this research contains these 3 steps (Fig. 1):

1) Improvement of water-related ecosystem services by choosing the best corrective agri-environmental measures;

2) criteria including quality and quantity of water and providing clean water in provisioning services, soil conservation and biodiversity in regulating services and agricultural tourism in cultural services group.

3) corrective agri-environmental measures including the proposed crop pattern (being conducted by Jahad-e-Keshavarzi research center and one of its goals being optimal use of water resources with regard to area limits), low irrigation, implementing conservative tillage, running integrated pest management (IPM), pressurized irrigation, watershed management projects and agri- tourism infrastructure development projects. 


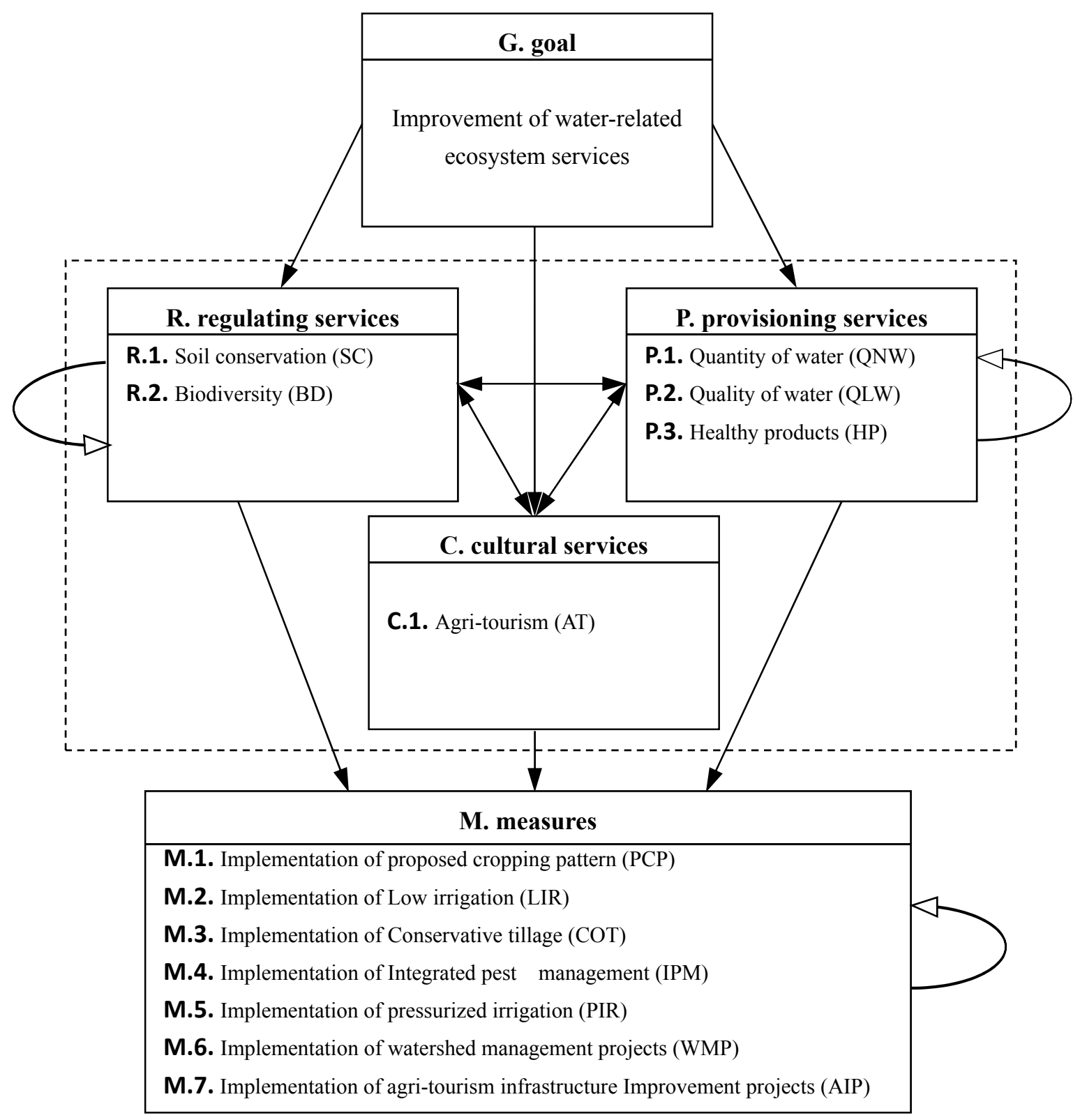

Figure 1. The proposed ANP hierarchy of this study

This model is so similar to that of hierarchical analysis process, except for that in this design, there is feedback and interconnections between ecosystem services and measures of each level (which is not true for AHP).

\subsection{Triangular Fuzzy Number (TFN)}

Since Zadeh introduced Fuzzy Set Theory (FST) in 1965 (Zadeh, 1965), many researchers have applied FST to solve complicated and vague problems Yang and Tzeng, 2011; Pedrycz, 1994; Hsieh, 2004; Wu et al., 2009; Chen, 2011). One of the major characteristics of FST is its capability of expressing vague data by natural language with linguistics. The theory also allows mathematical operators and programming to apply to the fuzzy domain (Leung et al., 2003). A fuzzy set is a class of objects with a continuum of grades of membership; it is described by a membership function that distributes to each object a grade of membership ranging between zero and one. Triangular Fuzzy Number (TFN) is one of the most commonly used in FST; according to the definition of van Larrhoven and Pedrycz, a TFN is the particular category of fuzzy number whose membership is defined by three real numbers, expressed as $(1, \mathrm{~m}, \mathrm{u})$, where $1 \leq \mathrm{m} \leq \mathrm{u}$ as shown in Fig. 2 . The value 1 denotes the smallest possible value; the value $\mathrm{m}$ denotes the most promising value; and the value $u$ denotes the largest possible value (van 
Laarhoven and Pedrycz, 1983). In this research, in order to include inherent uncertainty in decision making fuzzy interval is applied instead of crisp values (third column of Table 2).

Table 2. Membership function of linguistic scales

\begin{tabular}{ccc}
\hline Numerical scale & Linguistic scales & Triangular fuzzy scale (TFN) \\
\hline 1 & Just equal & $(1,1,1)$ \\
2 & Too Weakly more important & $(1,2,3)$ \\
3 & Very Weakly more important & $(2,3,4)$ \\
4 & Weakly more important & $(3,4,5)$ \\
5 & more important & $(4,5,6)$ \\
6 & Strongly more important & $(5,6,7)$ \\
7 & Very Strongly more important & $(6,7,8)$ \\
8 & Too Strongly more important & $(7,8,9)$ \\
9 & Absolutely more important & $(8,9,10)$ \\
\hline
\end{tabular}

The mathematical expression for the triangular membership function is presented in equation 1 . The interval is obtained after comparison of the 'ith' element with the 'jth' and is represented in the form of " $\widetilde{a}_{i j}$ ". The reciprocal of " $\widetilde{a}_{i j}$ " represents the preference of the 'jth' element over the 'ith' (equation 2) (Chang et al. 2015; Kumar and Maiti, 2012).

$$
\mu_{A}(x)=\left\{\begin{array}{cc}
\frac{(x-l)}{(m-l)} & l \leq x \leq m \\
\frac{(u-x)}{(u-m)} & m \leq x \leq u \\
0 & \text { otherwise }
\end{array}\right.
$$

Where

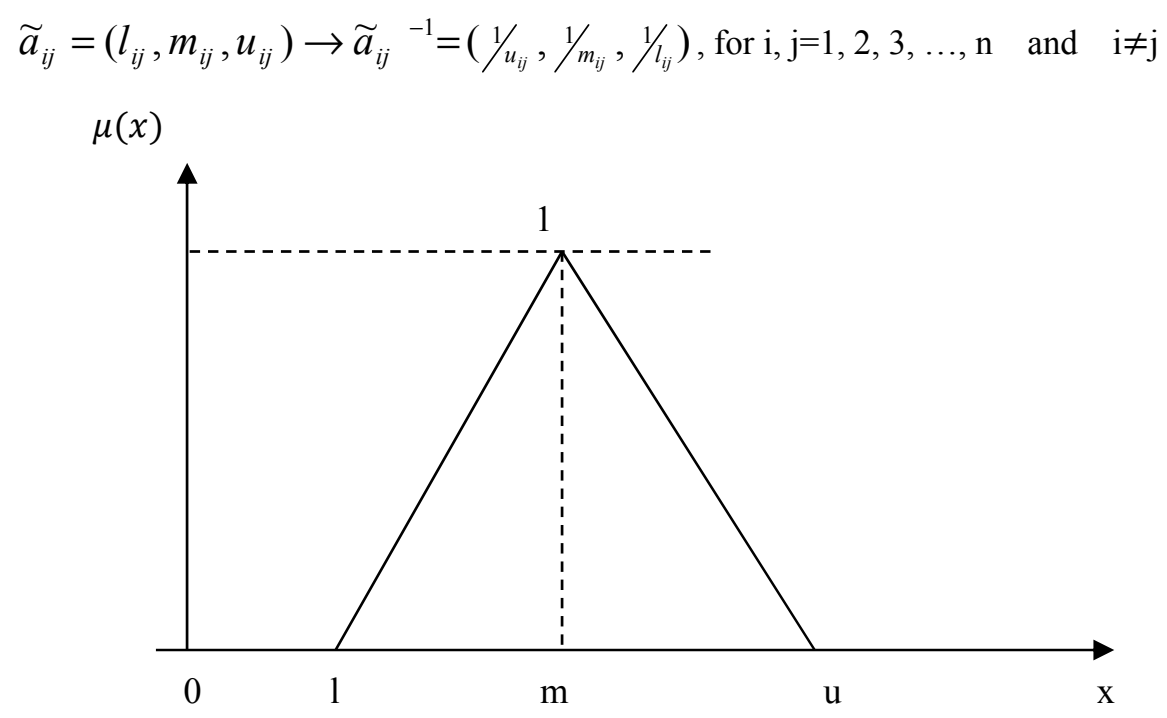

Figure 2. The triangular fuzzy number 
The fuzzy triangles for the linguistic terms for four sets of question is shown in Fig. 3. The decision maker selects a linguistic term based on the relative importance of the two alternatives being considered with respect to each criterion respectively.

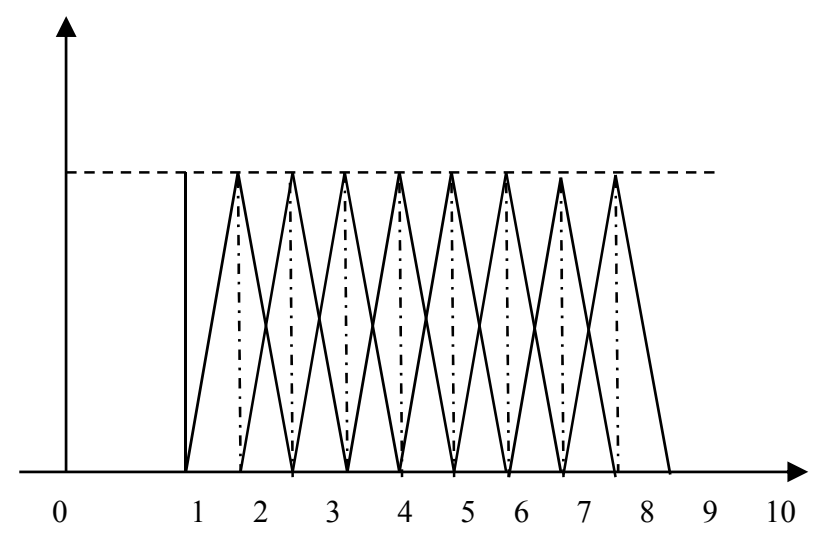

Figure 3. Membership triangles for the linguistic scales of importance (Table 1)

The comparison matrix is obtained for every control criterion as shown in Equation 3. " $a_{i j}$ " shows the degree of relative importance of the ith element in comparison to the jth element with respect to the control criterion.

$$
\widetilde{\mathrm{A}}=\left(\widetilde{a}_{i j}\right)_{m \times n}=\left[\begin{array}{cccc}
(1,1,1) & \left(l_{12}, m_{12}, u_{12}\right) & \mathrm{K} & \left(l_{1 n}, m_{1 n}, u_{1 n}\right) \\
\left(l_{21}, m_{21}, u_{21}\right) & (1,1,1) & \mathrm{K} & \left(l_{2 n}, m_{2 n}, u_{2 n}\right) \\
\mathrm{M} & \mathrm{M} & \mathrm{O} & \mathrm{M} \\
\left(l_{m 1}, m_{m 1}, u_{m 1}\right) & \left(l_{m 2}, m_{m 2}, u_{m 2}\right) & \mathrm{K} & (1,1,1)
\end{array}\right]
$$

\subsection{Estimation of the Priority Weights}

Since ANP can only works with crisp values, the fuzzy priority obtained must be converted into crisp priority vector. Different methods have been proposed but Fuzzy Extent Analysis proposed by Chang (1996) is straightforward and easy to apply. The steps of Chang's extended analysis is provided below (Kumar and Maiti, 2012).

Step 1- Compute the normalized value of row sums (i.e. fuzzy synthetic extent) by fuzzy arithmetic operations:

$$
\widetilde{S}_{i}=\sum_{j=1}^{n} \widetilde{a}_{i j} \otimes\left[\sum_{k=1}^{n} \sum_{j=1}^{n} \widetilde{a}_{k j}\right]^{-1}
$$

Step 2- Calculate the degree of possibility of $\widetilde{S}_{i} \geq \widetilde{S}_{j}$ by the following equation:

$$
\begin{gathered}
V\left(\widetilde{S}_{i} \geq \widetilde{S}_{j}\right)=\sup _{y \geq x}\left[\min \left(\widetilde{S}_{i}(x) \geq \widetilde{S}_{j}(y)\right)\right] \\
V\left(\widetilde{S}_{i} \geq \widetilde{S}_{j}\right)=\left\{\begin{array}{ccc}
1 & m_{i} \geq m_{j} \\
\frac{u_{i}-l_{j}}{\left(u_{i}-m_{i}\right)+\left(m_{j}-l_{j}\right)} & u_{i} \geq l_{j} \quad i, j=1,2, \ldots, n ; \quad j \neq i \\
0 & \text { otherwise }
\end{array}\right.
\end{gathered}
$$

where 


$$
\widetilde{S}_{i}=\left(l_{i}, m_{i}, u_{i}\right) \text { and } \widetilde{S}_{j}=\left(l_{j}, m_{j}, u_{j}\right)
$$

and $V\left(\widetilde{S}_{i} \leq \widetilde{S}_{j}\right)$ is the ordinate of the highest intersection point as shown in Fig. 4 .

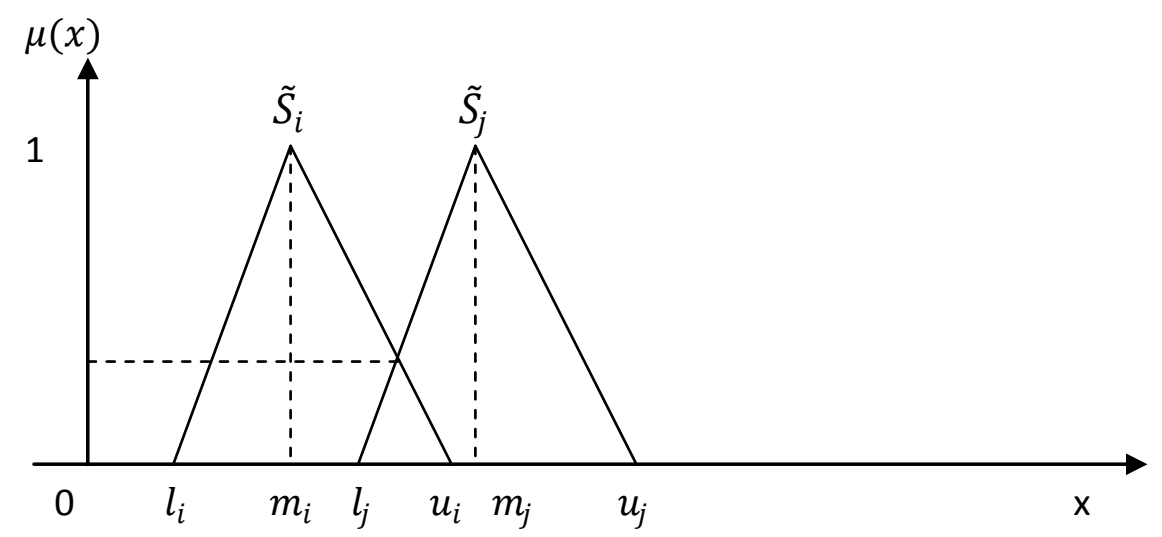

Figure 4. Degree of possibility of $\tilde{S}_{i} \geq \tilde{S}_{j}$

Step 3- Find the degree of possibility of $\tilde{S}_{i}$ to be greater than all the other (n-1) convex fuzzy numbers $\tilde{S}_{j}$ by:

$$
\left.V\left(\widetilde{S}_{i} \leq \widetilde{S}_{j}\right) \| j=1,2, \ldots, n ; \quad i \neq j\right)=\min _{j \in(1, \ldots, n) i \neq j}\left[V\left(\widetilde{S}_{i} \geq \widetilde{S}_{j}\right)\right] \quad i=1,2, \ldots, n
$$

Step 4- Obtain the weight or the priority vector $W=\left(w_{1}, w_{2}, \ldots, w_{n}\right)^{T}$ of the fuzzy comparison matrix $\widetilde{\mathrm{A}}$ is given by:

$$
w_{i}=\frac{V\left(\left(\widetilde{S}_{i} \geq \widetilde{S}_{j}\right) \mid j=1,2, \ldots, n ; \quad j \neq i\right)}{\sum_{k=1}^{n} V\left(\left(\widetilde{S}_{k} \geq \widetilde{S}_{j}\right) \mid j=1,2, \ldots, n ; \quad j \neq k\right)}, \quad i=1, \ldots, n
$$

\subsection{Estimation of Global Weights And Priorities}

The ANP method allows interactive dependence within clusters (inner dependence) and between clusters (outer dependence) by comparing the hierarchy structure in AHP with the network (Saaty, 2004; Saaty, 2005). Thus, limiting priority values within this supermatrix indicate the flow of influence of an individual element toward the overall goal. In a supermatrix, $\mathrm{W}$ is a standard form of a system-with-feedback supermatrix of clusters $\left\{C_{1}, C_{2}, \ldots, C_{n}\right\}$ and their linkages (or system weights) $W_{n n}$, where $C_{n}=\left\{e_{i 1}, e_{i 2}, \ldots, e_{i n}\right\}$ is the sub-cluster elements of the ith criterion component. Eigen vectors attained from a pair-wise comparison matrix are inserted in an orderly manner to form a matrix called the supermatrix. The column vector represents the impact, with respect to a control criterion, of a given set of elements of a component on a single element of the same or other component listed at the top. If there exists no relationship between two elements the related entry in the supermatrix is zero. The structure of the supermatrix, as indicated by Saaty (Saaty, 2004; Saaty, 2005), is shown in Eq. (9) (Chang et al. 2015; Kumar and Maiti, 2012). 


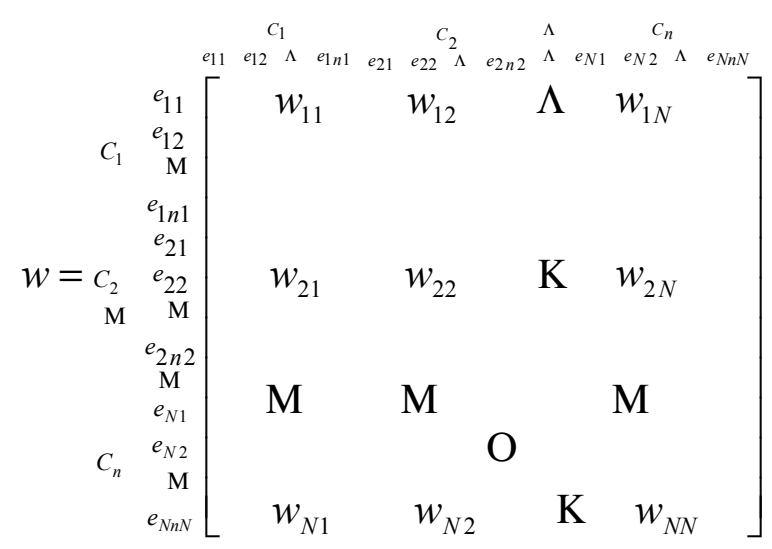

In this work there are three clusters namely $C_{1}$-goal, $C_{2}$-services and $C_{3}$-measures. The elements of the clusters are $e_{11}$-goal, $e_{21}$ - Quantity of water, $e_{22}$ - Quality of water and $e_{23}$ - Healthy products, $e_{24}$ - Soil conservation, $e_{25}$ - Biodiversity, $e_{26}$ - Agri-tourism, $e_{31}$ - cropping pattern, $e_{32}$ - Low irrigation, $e_{33}-$ Conservative tillage, $e_{34}$-Integrated pest management, $e_{35}$-pressurized irrigation, $e_{36}$-watershed management projects and $e_{37}$-agri-tourism infrastructure Improvement projects.

The actual elements that make up the columns of the supermatrix are the eigenvector solutions within the components. However, each column of the supermatrix may include several sub-columns with their own priority elements, which must be normalized and synthesized to account for the overall components' influence by column. This process makes the supermatrix column stochastic by the basic concept of the Markov Chain. The final priority weights that account for element interactions are derived by multiplying the supermatrix by itself until the columns are stabilized; the result is known as the limiting matrix (Chang et al. 2015).

\subsection{Collection of Data for Pair-Wise Comparison}

In order to achieve pair-wise comparison matrix, a questionnaire was designed to gather expert views in this topic. There were four sets of questions in this topic. In the first set, comparison between different criteria of three groups of ecosystem services in order to improve water-related ecosystems in Mashhad. In the second set, amount of influence of each group of ecosystem services criteria on each other is reviewed. Efficiency and influence of agri-environmental measures on water-related ecosystem services is the focus of the third set of questions. Finally, influence of agri-environmental measures on each other to improve already mentioned ecosystem services has been discussed.

To conduct pair-wise comparison, experts (including faculty members of agriculture, environment and natural resources of Ferdowsi university of Mashhad, University of applied sciences of Khorasan-e-Razavi, authorities of sustainable development section of national environmental protection organization, Jahad-e-Keshavarzi of Khorasan-e-Razavi and Mashhad experts, officials of environmental protection organization of Khorasan-e-Razavi, faculty members of research center of Jahad-e-Keshavarzi and two selected farmers (as representatives of farmers society)) were provided with a comparison scale. A comparison scale was provided to the experts for providing their responses (Table 1).

\section{Results}

The first step in using FANP is to form a hierarchy of dimensions and criteria for choice (Fig. 1) The weight of each factor is calculated by the TFN method. The fuzzy pair-wise comparisons matrix with respect to quantity of water is shown as in Table 3. 
Table 3. Fuzzy pair-wise comparison matrix of alternatives with respect to quantity of water service

\begin{tabular}{cccccc}
\hline Quantity of water & $\begin{array}{c}\text { Quality of } \\
\text { water }\end{array}$ & $\begin{array}{c}\text { Healthy } \\
\text { products }\end{array}$ & $\begin{array}{c}\text { Soil } \\
\text { conservation }\end{array}$ & Biodiversity & Agritourism \\
\hline Crop pattern & $(1,1,1)$ & $(1,2,3)$ & $(1,2,3)$ & $(1,1,1)$ & $(1,2,3)$ \\
Low irrigation & $(1 / 3,1 / 2,1)$ & $(1,1,1)$ & $(1,1,1)$ & $(1,1,1)$ & $(1,1,1)$ \\
Conservative tillage & $(1 / 3,1 / 2,1)$ & $(1,1,1)$ & $(1,1,1)$ & $(1,2,3)$ & $(1,2,3)$ \\
Biodiversity & $(1,1,1)$ & $(1,1,1)$ & $(1 / 3,1 / 2,1)$ & $(1,1,1)$ & $(1,1,1)$ \\
Agritourism & $(1 / 3,1 / 2,1)$ & $(1,1,1)$ & $(1 / 3,1 / 2,1)$ & $(1,1,1)$ & $(1,1,1)$ \\
\hline
\end{tabular}

In this research, we apply Equation 4 to calculate the fuzzy number as shown below:

$S_{q l}=(8,12,16) \otimes(47.08,34.78,26.42) \approx(0.170,0.345,0.650)$

Similarly,

$$
\begin{aligned}
& S_{h p} \approx(0.120,0.201,0.366) ; S_{s c} \approx(0.113,0.244,0.487) ; \\
& S_{b d} \approx(0.087,0.144,0.284) ; S_{a t} \approx(0.041,0.066,0.125)
\end{aligned}
$$

Using Equation 6,

$$
\begin{aligned}
& v\left(S_{q l} \geq S_{h p}\right)=1, v\left(S_{q l} \geq S_{s c}\right)=1, v\left(S_{q l} \geq S_{b d}\right)=1, v\left(S_{q l} \geq S_{a t}\right)=1 ; \\
& v\left(S_{h p} \geq S_{q l}\right)=0.577, v\left(S_{h p} \geq S_{s c}\right)=0.854, v\left(S_{h p} \geq S_{b d}\right)=1, v\left(S_{h p} \geq S_{a t}\right)=1 ; \\
& v\left(S_{s c} \geq S_{q l}\right)=0.759, v\left(S_{s c} \geq S_{h p}\right)=1, v\left(S_{s c} \geq S_{b d}\right)=1, v\left(S_{s c} \geq S_{a t}\right)=1 ; \\
& v\left(S_{b d} \geq S_{q l}\right)=0.363, v\left(S_{b d} \geq S_{h p}\right)=0.740, v\left(S_{b d} \geq S_{s c}\right)=0.630, v\left(S_{b d} \geq S_{a t}\right)=1 ; \\
& v\left(S_{a t} \geq S_{q l}\right)=0.000, v\left(S_{a t} \geq S_{h p}\right)=0.035, v\left(S_{a t} \geq S_{s c}\right)=0.063, v\left(S_{a t} \geq S_{b d}\right)=0.378
\end{aligned}
$$

Thus, according to Equations 7 and 8 , the numbers can be considered as follows:

$$
v\left(S_{q l}\right)=1 ; v\left(S_{h p}\right)=0.577 ; v\left(S_{s c}\right)=0.759 ; v\left(S_{b d}\right)=0.363 ; v\left(S_{a t}\right)=0
$$

Therefore:

$$
\begin{aligned}
& v_{q l}=(1,0.577,0.759,0.363,0) \\
& \text { and } \\
& w_{q l}=(0.371,0.214,0.281,0.314,0)
\end{aligned}
$$

Finally, after calculating all pair-wise fuzzy calculations, tables 4 and 5 , which show fuzzy matrix are attained in this study. After entering the acquired data of each questionnaire, compatibility index (C.I) and compatibility ratio (C.R) were examined and the arithmetic mean method is applied in sequence to integrate the data in this research.

Table 4. Fuzzy matrix with respect to the goal

\begin{tabular}{ccccccc}
\hline & $\begin{array}{c}\text { Quantity } \\
\text { of water }\end{array}$ & $\begin{array}{c}\text { Quality of } \\
\text { water }\end{array}$ & $\begin{array}{c}\text { Healthy } \\
\text { products }\end{array}$ & $\begin{array}{c}\text { Soil } \\
\text { conservation }\end{array}$ & Biodiversity & Agri-tourism \\
\hline $\begin{array}{c}\text { Quantity of } \\
\text { water }\end{array}$ & 1.000 & 0.000 & 0.521 & 0.000 & 0.384 & 0.124 \\
$\begin{array}{c}\text { Quality of water } \\
\text { Healthy }\end{array}$ & 0.371 & 1.000 & 0.210 & 0.000 & 0.384 & 0.115 \\
$\begin{array}{c}\text { products } \\
\text { Soil }\end{array}$ & 0.214 & 0.815 & 1.000 & 0.000 & 0.000 & 0.295 \\
$\begin{array}{c}\text { conservation } \\
\text { Biodiversity }\end{array}$ & 0.281 & 0.103 & 0.029 & 1.000 & 0.231 & 0.203 \\
Agri-tourism & 0.000 & 0.000 & 0.000 & 0.000 & 0.000 & 0.263 \\
\hline
\end{tabular}


Table 5. Fuzzy matrix with respect to services

\begin{tabular}{cccccccc}
\hline & PCP & LI & CT & IPM & PI & WMP & AIIP \\
\hline PCP & 1.000 & 0.000 & 0.000 & 0.000 & 0.000 & 0.000 & 0.000 \\
LIR & 0.058 & 1.000 & 0.000 & 0.000 & 0.000 & 0.000 & 0.000 \\
COT & 0.157 & 0.000 & 1.000 & 0.000 & 0.000 & 0.000 & 0.000 \\
IPM & 0.219 & 0.000 & 0.000 & 1.000 & 0.000 & 0.000 & 0.000 \\
PIR & 0.269 & 0.000 & 0.000 & 0.000 & 1.000 & 0.000 & 0.000 \\
WMP & 0.334 & 0.000 & 0.000 & 0.000 & 0.000 & 1.000 & 0.000 \\
AIP & 0.000 & 0.000 & 0.000 & 0.000 & 0.000 & 0.000 & 1.000 \\
\hline
\end{tabular}

Table 6 explains weighted values and ranking of each ecosystem services in water-related ecosystem services improvement and table 7 provides information about weights and rankings of agri-environmental measures of water-related ecosystem services improvement in agriculture section of Mashhad.

Table 6. Chang's priority weights and rankings of the ecosystem services

\begin{tabular}{|c|c|c|}
\hline ecosystem services & Priority weights & Ranking \\
\hline provisioning services & 0.793 & \\
\hline Quantity of water & 0.249 & 1 \\
\hline Quality of water & 0.272 & 2 \\
\hline Healthy products & 0.272 & 1 \\
\hline regulating services & 0.207 & \\
\hline Soil conservation & 0.107 & 3 \\
\hline Biodiversity & 0.101 & 4 \\
\hline cultural services & 0.000 & \\
\hline Agritourism & 0.000 & 5 \\
\hline
\end{tabular}

According to the results of this study, the first two priorities of water-related ecosystem services in Mashhad are water quantity and producing healthy products. In other words and as a result of this study, we can say that among water-related ecosystem services, water quality and having healthy products, weighted 0.272 , are first priorities. Providing needed water for agriculture section weighted 0.249 , stands in the second rank with minor difference. Third and fourth places go to soil protection $(0.107)$ and biodiversity $(0.101)$ relatively and at the moment, agricultural tourism which is categorized under cultural services is placed in the fifth place with a weighted value of zero.

Table 7. Chang's Priority weights of corrective measures with respect to the influence on services

\begin{tabular}{ccccccc}
\hline & $\begin{array}{c}\text { Quantity } \\
\text { of water }\end{array}$ & $\begin{array}{c}\text { Quality of } \\
\text { water }\end{array}$ & $\begin{array}{c}\text { Healthy } \\
\text { products }\end{array}$ & $\begin{array}{c}\text { Soil } \\
\text { conservation }\end{array}$ & Biodiversity & Agri-tourism \\
\hline PCP & 0.330 & 0.692 & 0.000 & 0.219 & 0.200 & 0.000 \\
LIR & 0.135 & 0.000 & 0.000 & 0.000 & 0.000 & 0.000 \\
COT & 0.275 & 0.000 & 0.000 & 0.561 & 0.351 & 0.000 \\
IPM & 0.000 & 0.308 & 1.000 & 0.219 & 0.449 & 0.288 \\
PIR & 0.135 & 0.000 & 0.000 & 0.000 & 0.000 & 0.000 \\
WMP & 0.124 & 0.000 & 0.000 & 0.000 & 0.000 & 0.000 \\
AIP & 0.000 & 0.000 & 0.000 & 0.000 & 0.000 & 0.712 \\
\hline
\end{tabular}


Furthermore, the results show that among the seven agri-environmental water-related ecosystem services enhancement (extracted from authentic documents and related rules and regulation), IPM, weighted 0.422, ranks first. Also, the second priority goes to proposed crop pattern of Jahad-e-Keshavarzi Research center (one of its main goals being the standardization of water consumption in Mashhad plain) with value of 0.207 (Table 8).

Table 8 . Chang's priority weights and rankings of agri-environmental measures of water-related ecosystem services improvement

\begin{tabular}{ccc}
\hline Measures & Priority weights & Ranking \\
\hline proposed cropping pattern (PCP) & 0.207 & 2 \\
Low irrigation (LIR) & 0.037 & 6 \\
Conservative tillage (COT) & 0.162 & 3 \\
Integrated pest management (IPM) & 0.422 & 1 \\
pressurized irrigation (PIR) & 0.081 & 5 \\
watershed management projects (WMP) & 0.092 & 4 \\
Agri-tourism infrastructure Improvement projects (AIP) & 0.000 & 7 \\
\hline
\end{tabular}

According to acquired information from FANP analysis, it can be seen that conservative tillage with a value of 0.162 is the third priority among the above mentioned seven agri-environmental measures. The results also show that fourth and fifth places of these measures, with a meaningful difference to the first three priorities, host watershed management projects and pressurized irrigation with weights of 0.092 and 0.081 respectively. Not to prove that these are not important projects, this means that to fully benefit from them, we need to select appropriate product for an area to plant and if not, most of the cost will be wasted through inappropriate choice of product for the selected area.

In addition, we need to consider that one of the goals of agriculture section (following the excessive consumption of water and soil resources) is reaching food security through standard quantity and quality of agricultural products. Whilst, using all these precious resources inappropriately results in unhealthy products, therefore, the main objective cannot be achieved. In this regard it is important to pay as much as necessary attention to this issue.

The findings also show that low irrigation weighted 0.037 placed sixth and agriculture tourism infrastructure enhancement project is weighted zero and paced last.

Comparison between prioritized ecosystem services and agri-environmental measures proves a notable harmony. For example, as mentioned before, water quantity, healthy product and water quality are closely weighted and our two priorities of ecosystem services, therefore, it is logical to expect parallel measures in programming and implementing be those with highest efficiency on these services. According to this logical expectation, the two measures which weigh about $63 \%$ of total among the seven agri-environmental measures are IPM and implementing proposed crop pattern of Jahad-e-Keshavarzi Research center. It goes without saying that IPM is the most effective action on having healthy products and preventing water pollution (as a result of mismanagement of poison and chemical fertilizers), and soil conservation and implementing proposed crop pattern of Jahad-e-Keshavarzi research Center whose main goal is optimization of water resources consumption will highly affect available water resource in Mashhad.

According to the findings, conservative tillage implementation stands in the third place of agri-environmental measures whose effect on water quality and quantity, soil conservation and biodiversity is obvious.

\section{Discussion}

With increase in population comes intensive farming and inappropriate methods of agricultural producers, resulting in damages to the environment of agriculture section and natural resources leading to unhealthy agricultural products. This means that unless the current methods of different agricultural input consumption is revised in short time, ecosystem services from which human beings benefit will be negatively affected. One of these services is water-related ecosystem services which include different provisioning, regulating, cultural and supporting services.

Protecting these ecosystems and their associated services in programs, documents and authentic regulations inside the framework of plans or agri-environmental measures is done differently in different countries. In Iran in general 
and Mashhad agriculture section specifically, these measures for improving water-related ecosystem services is underway including design and implementation of crop pattern in different areas, conservative tillage, integrated pest management (IPM), low irrigation, implementing pressurized irrigation systems, watershed management programs and agri-tourism infrastructure. In addition to their influence on one another, these measures are effective on some of the ecosystem services mentioned above. It is needless to say that all these require enough budgets and a long time. Therefore, it is essential that prioritized measures regarding current condition of Mashhad environment and agriculture and its limitations and available facilities be considered first.

In order to identify prioritized agri-environmental measures and due to mutual influence of these measures and ecosystem service on each other, FANP technique was used in this research so that pair-wise comparisons of experts of this area in university, supervision and implementation scopes becomes easier.

The findings of this research show that the first priority is provisioning services at the moment. The second priority is regulating services and according to experts of this area cultural services stand in the last place. In provisioning services, water quality and healthy products stand in the first place with water quantity ranking second (this ranking is true for all measures). According to this, IPM implementation, design and application of proposed crop pattern aiming at optimization of water resources and conservative tillage rank first to third in water-related ecosystem services improvement of agri-environmental measures in Mashhad.

It has to be emphasized that according to the principles of management, structure design and policies of all areas specially environment (having numerous beneficiaries) does not work without views of associated groups and beneficiaries and after identifying prioritized measures, it is necessary to collect their ideas about ways of implementing and running these schemes in order to succeed and have the support of those groups.

It is then suggested that having the required views of experts and prioritized measures, we need to blend these in different plans together with other parameters influencing farmers decisions about co operating with them (like cancellation policy, length of the scheme and measure of supervision on the scheme and so on.) so that the best and optimal way of cooperation with farmers of Mashhad for implementing these measures is selected. It is obvious that different farmers will choose different schemes depending on their land properties and location, access to resources and different agri-environmental levels.

We should bear in mind that in today's world, environment is known as a public good, and providing public goods is mostly a government's duty. Therefore, successful implementation of such schemes requires support and bonuses for those farmers who cooperate.

\section{References}

Atmaca, E.,\& Basar, H. B. (2012). Evaluation of power plants in Turkey using Analytic Network Process (ANP). Energy, 44, 555-563. https://doi.org/10.1016/j.energy.2012.05.046

Bingjie Song, B., Robinson, G. M., \& Zhou, Zh. (2017). Agricultural transformation and ecosystem services: A case study from Shaanxi Province, China. Habitat International, 69, 114-125. https://doi.org/10.1016/j.habitatint.2017.09.008

Chang, B., Kuoa, Ch., Wub, Ch., \& Tzeng, G. (2015). Using Fuzzy Analytic Network Process to assess the risks in enterpriseresource planning system implementation. Applied Soft Computing, 28, 196-207. https://doi.org/10.1016/j.asoc.2014.11.025

Chen, V. Y. C., Lien, H. P., Liu, C. H., Liou, J. J. H., Tzeng, G. H., \& Yang, L. S. (2011). Fuzzy MCDM approach for selecting the best environment-watershed plan. Applied Soft Computing, 11(1), 265-275. https://doi.org/10.1016/j.asoc.2009.11.017

Chopra, K., Leemans, R., Kumar, P., \& Simons, H. (2005). Ecosystems and Human Well-being: Policy Responses. Millennium Ecosystem Assessment Board, 3, 213-257.

Costanza, R., d'Arge, R., de Groot, R., Farber, S., \& Grasso, M. (1997). The value of the world's ecosystem services and natural capital. Nature, 387, 53-260. https://doi.org/10.1038/387253a0

Costanza, R., Ralph, D. A., Rudolf, D. G., Stephen, F., Monica, G., Bruce, H., ... Marjan, V. D. B. (1997). Value of the world's ecosystem services and natural capital. Nature, 387, 253-260. https://doi.org/10.1038/387253a0

Costanza, R.,\& Farber, S. (2002). Introduction to the special issue on the dynamics and value of ecosystem services: integrating economic and ecological perspectives. Ecological Economics, 41, 367-373. https://doi.org/10.1016/S0921-8009(02)00087-3 
Darvishi, A. A. (1993). Iran's capacity for sustainable agricultural development. Quarterly Journal of Agricultural Economics and Development (Persian), 5, 30-53.

Davari, K., Omranian Khorasani, H., \& Ghanbari, F. (2015). Water strategy document of Mashhad.

Ehrlich, P. R., \& Ehrlich, A. H. (1981). Extinction: the causes and consequences of the disappearance of species. Random House, New York.

Einollahi, B. (2013). Per capita consumption of agricultural poisons (Report No. 2039359). Retrieved from https://www.mehrnews.com/news/2039359

European Commission. (1997). Report to the European Parliament and to the council on the application of council regulation (EEC) No. 2078/92 on Agricultural Production Methods compatible with the requirements of the protection of the environment and the maintenance of the countryside. European Commission Directorate-General for Agriculture.

Grizzetti, B., Lanzanova, D., Liquete, C., Reynaud, A., \& Cardoso, A. C. (2016). Assessing water ecosystem services for water resource management. Environmental Science \& Policy, 61, 194-203. https://doi.org/10.1016/j.envsci.2016.04.008

Guerry, A. D., Polasky, S., Lubchenco, J., Chaplin-Kramer, R., Daily, G. C., Griffin, R., \& Ruckelshaus, M. (2015). Natural capital and ecosystem services informing decisions: from promise to practice. Proceedings of the National Academy of Sciences of the United States of America, 112, 7348-7355. https://doi.org/10.1073/pnas.1503751112

Haines-Young, R., Potschin, M., \& Kienast, F. (2012). Indicators of ecosystem service potential at European scales: mapping marginal changes and trade-offs. Ecological Indicators, 21, 39-53. https://doi.org/10.1016/j.ecolind.2011.09.004

Hsieh, T. Y., Lu, S. T., \& Tzeng, G. H. (2004). Fuzzy MCDM approach for planning and design tenders selection in public office buildings. International Journal of Project Management, 22(7), 573-584. https://doi.org/10.1016/j.ijproman.2004.01.002

Hughes, J., \& Brooks, S. (2009). Living landscapes: towards ecosystem-based conservation in Scotland Edinburgh. Scottish Wildlife Trust.

Islamic Parliament of Islamic Republic of Iran. (2011). The Fifth Development Plan of the Islamic Republic of Iran.

Islamic Republic of Iran. (2003). The general policies of the Islamic Republic of Iran.

Javadzadeh, M. (2014). Agri-environmental development in Iran challenges and strategies. Applied Science Reports, 3(1), 6-11.

Jongman, R. H. G. (2002). Homogenisation and fragmentation of the European landscape: ecological consequences and solutions. Landscape Urban Plan, 58, 211-221. https://doi.org/10.1016/S0169-2046(01)00222-5

Kumar, G., \& Maiti, J. (2012). Modeling risk based maintenance using fuzzy analytic network process. Expert Systems with Applications, 39(11), 9946-9954. https://doi.org/10.1016/j.eswa.2012.01.004

Lele, S. (2009). Watershed services of tropical forest: from hydrology to economic valuation of integrated analysis. Current opinion in environmental sustainability, 1(2), 148-155. https://doi.org/10.1016/j.cosust.2009.10.007

Leung, L. C., Hui, Y. V., \& Zheng, M. (2003). Analysis of compatibility between interdependent matrices in ANP. J. Oper. Res. Soc., 54, 758-768. https://doi.org/10.1057/palgrave.jors.2601569

MEA (Millennium Ecosystem Assessment). (2005). Ecosystems and human well-being: A framework for assessment. MA (Millennium Ecosystem Assessment). Retrieved from http://www.millenniumassessment.org/en/Framework.html

Ministry of Power of Islamic Republic of Iran. (2009). Master Plan of water basins of east of Iran with a focus on Karakum basin.

Monitoring network. (2012). Monitoring network of water quality of Mashhad aquifer. A water research company. Mashhad.

Najafinasab, F., Karbassi, A, R., \& Ghoddousi, J. (2015). Fuzzy analytic network process approach to evaluate land and sea criteria for land use planning in coastal areas. Ocean \& Coastal Management, 116, 368-381. https://doi.org/10.1016/j.ocecoaman.2015.07.023 
OECD. (2003). Agri-environmental Policy Measures: Overview of Developments. Ordination for Economic Cooperation and Development, Paris.

Ojea, E., Martin-Ortega, J., \& Chiabai, A. (2012). Defining and classifying ecosystem services for economic valuation: the case of forest water services. Environmental science and policy, 19-20, 1-15. https://doi.org/10.1016/j.envsci.2012.02.002

Organization of Management and Planning of Islamic Republic of Iran. (2005). National document of special (multi-sectoral) development of Iran Water Resources Management.

Pedrycz, W. (1994). Why triangular membership functions? Fuzzy Sets and Systems, 64(1), 21-30. https://doi.org/10.1016/0165-0114(94)90003-5

Ran, Y., Deutsch, L., Lannerstad, M., \& Heinke, J. (2013). Rapidly intensified beef production in Uruguay: Impacts on water-related ecosystem services. Aquatic procedia, 1, 77-87. https://doi.org/10.1016/j.aqpro.2013.07.007

Rigg, J. (1998). Ruraleurban interactions, agriculture and wealth: A southeast Asian perspective. Progress in Human Geography, 22(4), 497-522. https://doi.org/10.1191/030913298667432980

Robinson, G. M., \& Carson, D. A. (2015). The globalization of agriculture: Introducing the handbook. In G. M. Robinson, \& D. A. Carson (Eds.), Handbook on the globalization of agriculture (pp. 1-28). Cheltenham: Edward Elgar. https://doi.org/10.4337/9780857939838.00006

Saaty, T. L. (2004). Decision Making with Dependence and Feedback: The analytic network process. RWS Publication, Pittsburgh, USA.

Saaty, T. L. (2005). Theory and Applications of the Analytic Network Process: Decision Making: Decision Making with Benefits, Opportunities, Costs, and Risks. RWS Publications, Pittsburgh, PA 15213, USA.

Scottish Government. (2011). Applying an ecosystems approach to land use: information note. Retrieved from http://www.scotland.gov.uk/Resource/Doc/345453/0114927

Shafiee, M. (2015). A fuzzy analytic network process model to mitigate the risks associated with offshore wind farms. Expert Systems with Applications, 42, 2143-2152. https://doi.org/10.1016/j.eswa.2014.10.019

Shahnoushi, N. (2014). Organizing and formation water market in Khorasan-e-Razavi. Research project, Client: Regional Water Company of Khorasan-e-Razavi. Administration: Ferdowsi university of Mashhad.

Stoate, C., Boatman, N. D., Borrahlon, R. J., Carvalho, C. R., de Snoo, G. R., \& Eden, P. (2002). Ecological impacts of arable intensification in Europe. Journal of Environmental Management, 63, 337-365. https://doi.org/10.1006/jema.2001.0473

TEEB. (2010). The Economics of Ecosystems and Biodiversity: Ecological and Economic Foundation. Earthscan, London and Washington.

The Council of Ministers of Islamic Republic of Iran. (2003). Long-term strategies for the development of water resources of Islamic Republic of Iran.

The Council of Ministers of Islamic Republic of Iran. (2008). National document of Khorasan-e-Razavi development.

Theobald, D. M. (2001). Land-use dynamics beyond the American urban fringe. Geographical Review, 91(3), 544-564. https://doi.org/10.2307/3594740

UKNEA. (2011). UK NEA synthesis of findings. Retrieved from http://uknea.unepwcmc.org

van Laarhoven, P. J. M., \& Pedrycz, W. (1983). A fuzzy extension of Saaty's priority theory. Fuzzy Sets and Systems, 11, 229-241. https://doi.org/10.1016/S0165-0114(83)80082-7

Vörösmarty, C. J., McIntyre, P. B., Gessner, M. O., Dudgeon, D., Prusevich, A., Green, P., ... Davies, P. M. (2010). Global threats to human water security and river biodiversity. Nature, 467, 555-561. https://doi.org/10.1038/nature09440

Wilson, G. A. (1997). Factors influencing farmer participation in the environmentally sensitive areas scheme. Journal of Environmental Management, 50, 67-93. https://doi.org/10.1006/jema.1996.0095

Working Document. (1998). State of the application of regulation (EEC) No. 2078/92: Evaluation of Agri-Environment Programmes VI/7655/98. 
Wu, H. Y., Tzeng, G. H., \& Chen, Y. H. (2009). A fuzzy MCDM approach for evaluating banking performance based on Balanced Scorecard. Expert Systems with Applications, 36(6), 10135-10147. https://doi.org/10.1016/j.eswa.2009.01.005

Yang, J. L., \& Tzeng, G. H. (2011). An integrated MCDM technique combined with DEMATEL for a novel cluster-weighted with ANP method. Expert Systems with Applications, 38(3), 1417-1424. https://doi.org/10.1016/j.eswa.2010.07.048

Yang, L., Zhang, L., Li, Y., \& Wu, S. (2015). Water-related ecosystem services provided by urban green space: A case study in Yixing City (China). Landscape and Urban Planning, 136, 40-51. https://doi.org/10.1016/j.landurbplan.2014.11.016

Zadeh, L. A. (1965). Fuzzy sets. Information and Control, 8(3), 338-353. https://doi.org/10.1016/S0019-9958(65)90241-X

Zasada, I. (2011). Multifunctional peri-urban agricultureda review of societal demands and the provision of goods and services by farming. Land Use Policy, 28(4), 639-648. https://doi.org/10.1016/j.landusepol.2011.01.008

\section{Copyrights}

Copyright for this article is retained by the author(s), with first publication rights granted to the journal.

This is an open-access article distributed under the terms and conditions of the Creative Commons Attribution license (http://creativecommons.org/licenses/by/4.0/). 